\title{
Theories on the Blue Wing Road Burial (41BX34) in the Context of the Gutiérrez-Magee Expedition
}

\author{
Brandon K. Richards \\ Energy Renewal Partners
}

Follow this and additional works at: https://scholarworks.sfasu.edu/ita

Part of the American Material Culture Commons, Archaeological Anthropology Commons, Environmental Studies Commons, Other American Studies Commons, Other Arts and Humanities Commons, Other History of Art, Architecture, and Archaeology Commons, and the United States History Commons

Tell us how this article helped you.

This Article is brought to you for free and open access by the Center for Regional Heritage Research at SFA ScholarWorks. It has been accepted for inclusion in Index of Texas Archaeology: Open Access Gray Literature from the Lone Star State by an authorized editor of SFA ScholarWorks. For more information, please contact cdsscholarworks@sfasu.edu. 


\section{Theories on the Blue Wing Road Burial (41BX34) in the Context of the Gutiérrez- Magee Expedition}

\section{Licensing Statement}

Reproduction, posting, transmission, or other distribution or use of the Journal volume, individual article or any portion of the material therein, in any medium, is permitted strictly for personal, non-commercial purposes via a personal-use exemption under a Creative Commons license granted by JTAH.org, Inc. This license exemption requires, as a condition of its granted permission, proper credit be attributed to JTAH.org as copyright holder (e.g., Journal of Texas Archeology and History.org @ 2017). No part of this publication may be reproduced, posted, transmitted, or otherwise utilized or distributed in any form by any means or method for commercial purposes without the express written consent of the Publisher. Inquiries should be addressed to JTAH Publisher, Suite 307, Box 361, 5114 Balcones Woods Drive, Austin, Texas, 78759.

The Journal of Texas Archeology and History.org is an organization dedicated to furthering research, education and public outreach in the fields of archeology and history concerning Texas and its bordering states of Louisiana, Arkansas, Oklahoma, New Mexico and Northern Mexico; a region we call the "Texas Borderlands." The J.T.A.H. is collaborating with the Index of Texas Archaeology and S.F.A.S.U. to distribute their publication library to the general public via free and open-access channels. Visit www.JTAH.org to submit an article. 


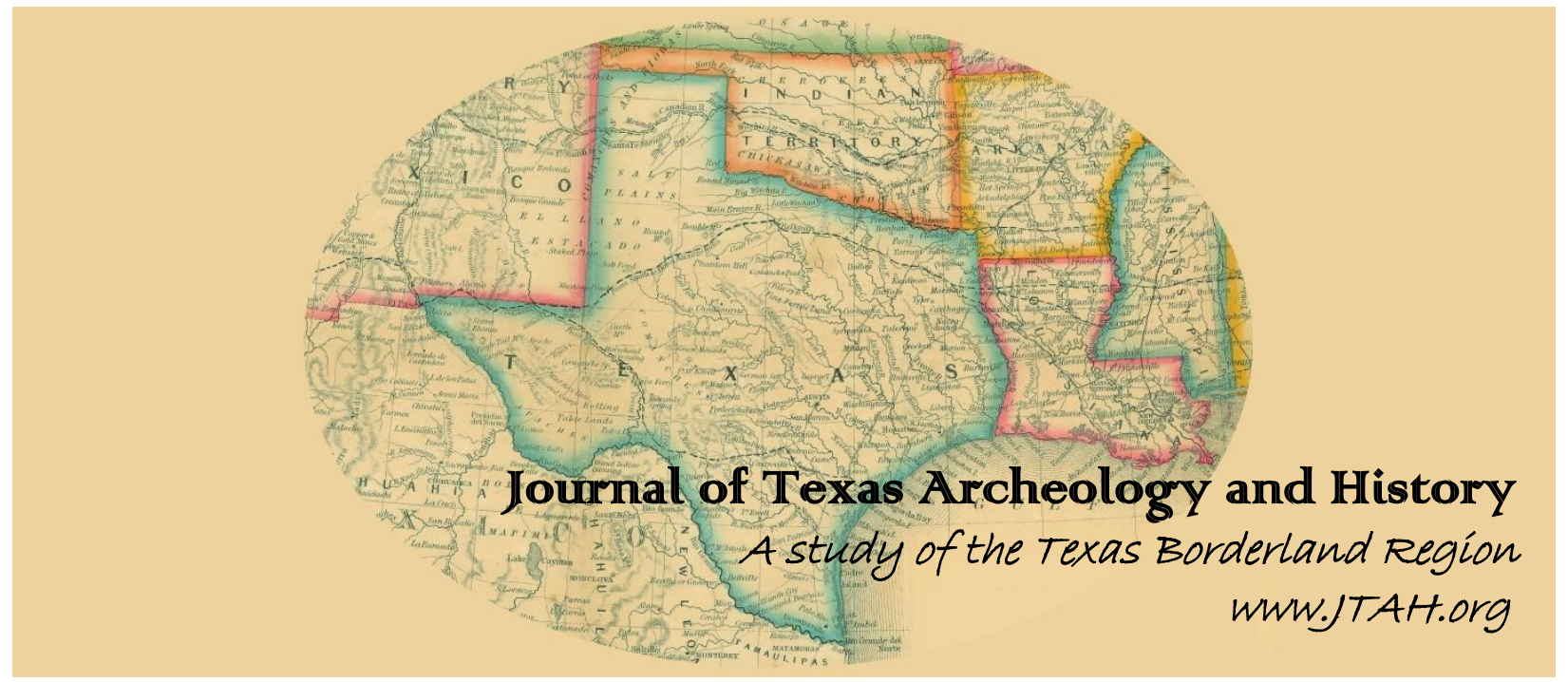

\section{Article Title: THEORIES ON THE BLUE WING ROAD BURIAL (41BX34) IN THE CONTEXT OF THE GUTIÉRREZ-MAGEE EXPEDITION}

\section{Author(s): $\quad$ Brandon K. Richards}

Original Source: J.T.A.H. Volume 3 (2016/2017), Article 3, pp. 83 - 96; online 16 July 2017

Recommended Citation: Richards, Brandon K.; "Theories on the Blue Wing Road Burial (41BX34) in the Context of the Gutiérrez-Magee Expedition", (2017), Journal of Texas Archeology and History Volume 3 (2016/2017), pp. 83 - 96.

Copyright $(C 2017$ by Journal of Texas Archeology and History.org, Inc. All rights reserved.

Online/Digital publication: ISSN 2334-1874

The online, digital, and print versions of the publication "Journal of Texas Archeology and History" are published by

Journal of Texas Archeology and History.org, Inc., a Texas nonprofit IRC Section 501(c)(3) corporation.

Reproduction, posting, transmission, or other distribution or use of the Journal volume, individual article or any portion of the material therein, in any medium, is permitted strictly for personal, non-commercial purposes via a personal-use exemption under a Creative Commons license granted by JTAH.org, Inc. This license exemption requires, as a condition of its granted permission, proper credit be attributed to JTAH.org as copyright holder (e.g., Journal of Texas Archeology and History.org (C) 2017). No part of this publication may be reproduced, posted, transmitted, or otherwise utilized or distributed in any form by any means or method for commercial purposes without the express written consent of the Publisher. Inquiries should be addressed to JTAH Publisher, Suite 307, Box 361, 5114 Balcones Woods Drive, Austin, Texas, 78759

The Journal of Texas Archeology and History.org is an organization dedicated to furthering research, education and public outreach in the fields of archeology and history concerning Texas and its bordering states of Louisiana, Arkansas, Oklahoma, New Mexico and Northern Mexico; a region we call the "Texas Borderlands." The J.T.A.H. is collaborating with the Index of Texas Archaeology and S.F.A.S.U. to distribute their publication library to the general public via free and open-access channels. Visit www.JTAH.org to submit an article. 


\title{
THEORIES ON THE BLUE WING ROAD BURIAL (41BX34) IN THE CONTEXT OF THE GUTIÉRREZ-MAGEE EXPEDITION
}

\author{
Brandon K. Richards \\ Energy Renewal Partners
}

\begin{abstract}
In 1968, the skeletal remains of an individual believed to have been involved in the Gutiérrez-Magee expedition of 1812-1813 were exhumed south of San Antonio. Since then, the circumstances surrounding what became known as the "Blue Wing Road burial" have remained somewhat of a mystery. This article introduces a new theory that posits that the burial is not directly related to the major battles fought in the region (the Battles of Rosalis and Medina), but more likely an incident involving a Republican detachment encountering Royalists stationed along a well-travelled route.
\end{abstract}

\section{INTRODUCTION}

In 1968, a road grading crew stumbled across exposed human bones alongside Blue Wing Road south of San Antonio (Figure 1). Archeologists Anne Fox and Helen Weeks of the Witte Museum were brought in to exhume the skeletal remains, recovering a large lead ball that was lodged under the individual's chin, as well as seven, plain copper clothing buttons, in the process (Figure 2). Since the isolated discovery, the circumstances surrounding the Blue Wing Road burial have remained somewhat of a mystery. Some had speculated that the remains were those of Colonel Miguel Menchaca (Schwarz and Thonhoff 1985:129-130; Eckhardt 1997:36), who, as the story goes, was struck in the neck and killed during the Battle of Medina on August 18, 1813 (Schwarz and Thonhoff 1985:101; Matovina and de la Teja 2013:52; Folsom 2014:105). Although contemporary research has provided evidence that the remains were not those of Menchaca (Munoz 2014), there have been few published theories on the burial in the context of the historical backdrop and geographic landscape. This article introduces new theories related to the circumstances surrounding Bexar County archeological site 41BX34, better known as the Blue Wing Road burial.

\author{
JOURNAL OF TEXAS ARCHEOLOGY AND HISTORY \\ VOLUME 3:83-96 \\ THE ONLINE PUblicATION JOURNAL OF TEXAS ARCHEOLOGY AND HISTORY (ISSN 2334-1874) \\ IS PUBLISHED BY JOURNAL OF TEXAS ARCHEOLOGY AND HISTORY.ORG. \\ COPYRIGHT (C) 2017 JOURNAL OF TEXAS ARCHEOLOGY AND HistORY.ORG. ALL RIGHTS RESERVED.
}




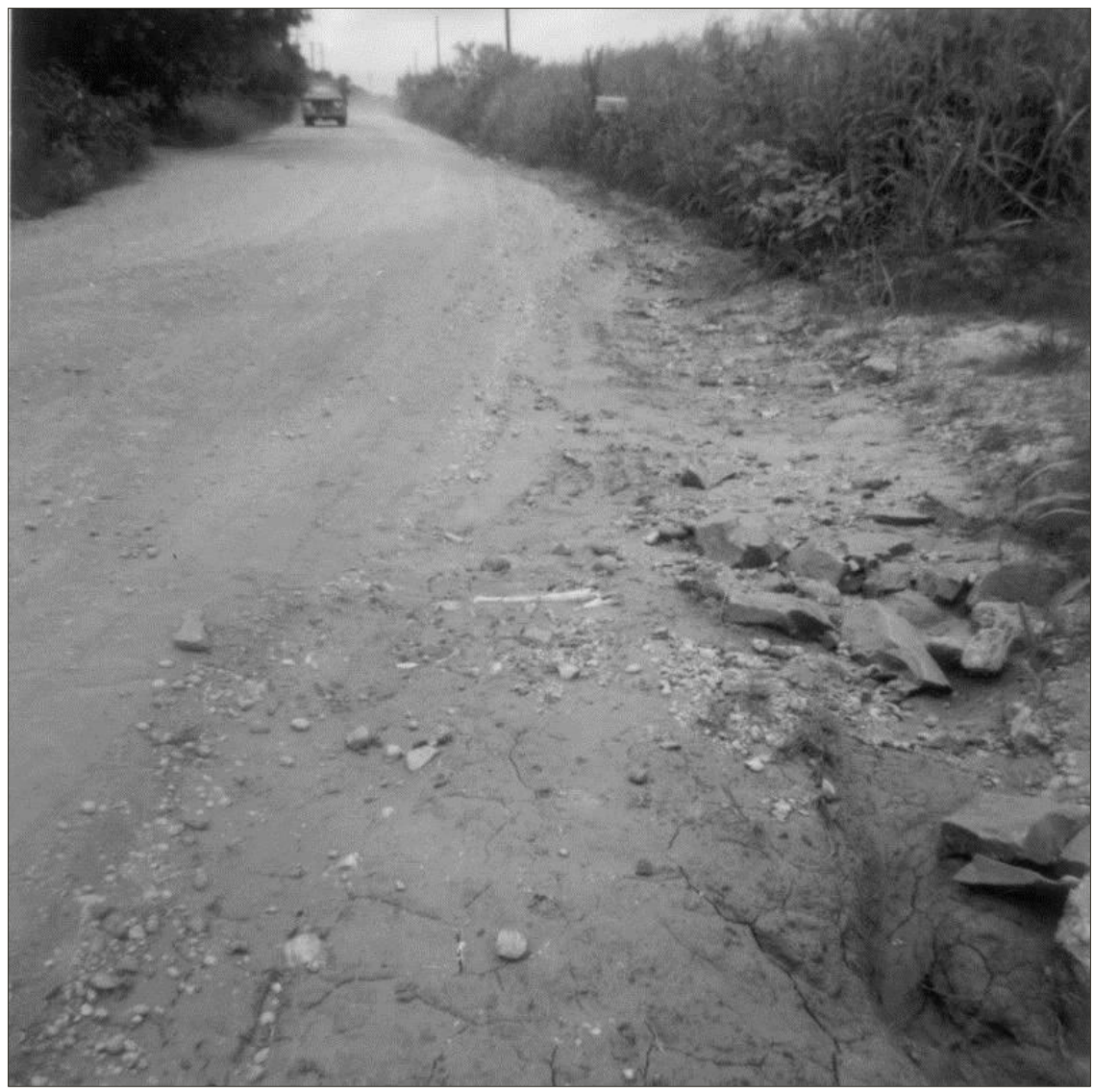

Figure 1. Blue Wing Road at the time of the burial discovery. Photo courtesy of UTSA Center for Archaeological Research .

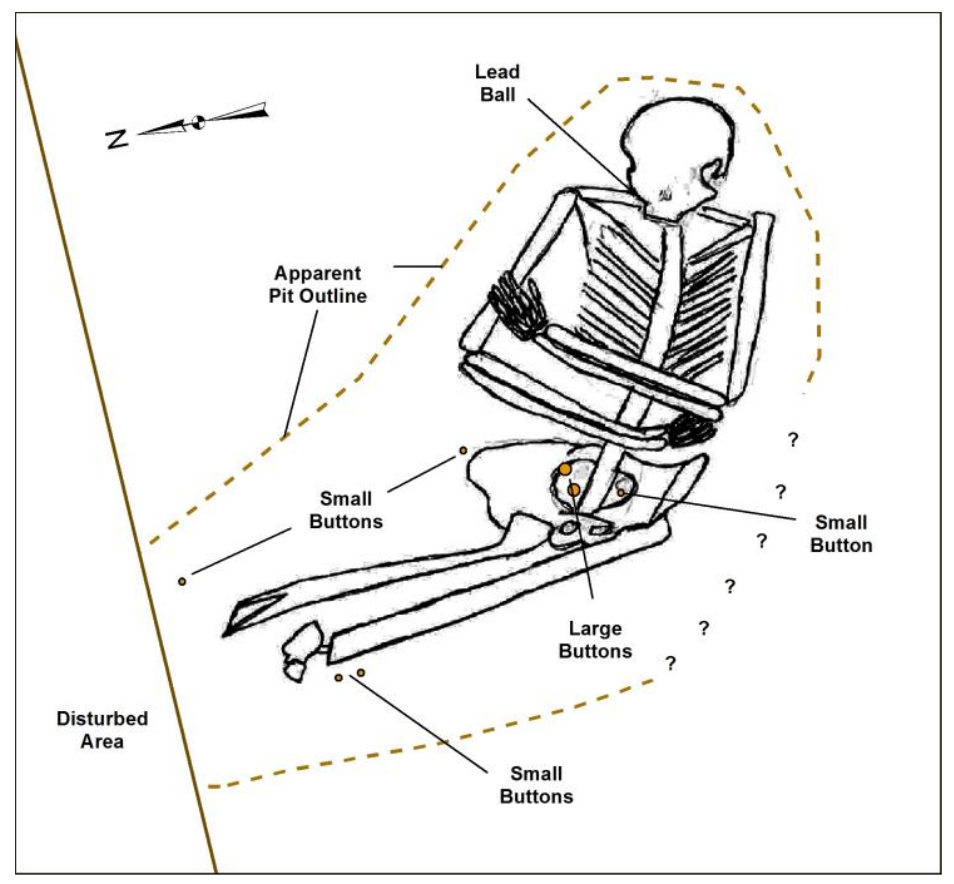

Figure 2. Sketch of the Blue Wing Road burial (41BX34) based on field notes. Drawing by Matthew Richards and Brandon Richards. 


\section{SKELETAL ANALYSIS}

Dr. Barbara Butler of North Texas State University analyzed the exhumed remains and presented her findings to Dr. Anne Fox in a 1974 letter (Butler 1974). In her results summary, Dr. Butler provided an age at death range of 22 to 28 years based on McKern and Stewart's (1957) pubic symphysis. A height of $5 \mathrm{ft} 7$ in was also determined using the Trotter and Gleser (1958) regression

formula. This calculation was made using the ulna, the only complete long bone, as the lower parts of both legs were missing and the remaining leg bones fragmented due to post-mortem breakage. In addition, she stated that the individual was male based on the robustness of the bones, the pronounced muscle markings, the large size of the mastoid process, and the small angle of the pelvic sciatic notch. Furthermore, it was noted that the incisors were not shovel shaped, introducing the likelihood that the individual was of European descent or admixture (Dixon 1999:20-21).

The skeletal analysis revealed two healed bone fractures as well. The first was a Colles' fracture, the common result of one suffering a hard fall on outstretched hands. This injury was represented by the deformed distal end of the right radius. Moreover, the anterior surface (palm side) was deflected posteriorly, beginning about $4 \mathrm{~mm}$ from the distal end of the bone. A second healed fracture was identified in the mid-shaft region of the right ulna. This fracture, a Parry fracture, is a common defensive wound resulting from an arm being used to shield a blow (Larsen 2015:122-124). Although both injuries together could have been suffered in an accident unrelated to interpersonal violence (Knüsel and Smith 2014:102), they are nevertheless consistent with what a soldier might experience at some point during a career.

\section{ADDITIONAL SITE FINDINGS}

One of the most significant discoveries relating to the burial was that a large lead ball, measuring more than $30 \mathrm{~mm}$ (over an inch) in diameter (Figure 3) and weighing 4 ounces, was lodged just below the right side of the individual's chin. This suggests the individual died from wounds suffered in an armed conflict. Because of the size of the ball, it could not have been fired from a musket (Haecker and Mauck 1997:135; Tucker 2011:526-527). It would have to come from a grape or canister shot, which is typically fired from a cannon at close range to be most effective (Farwell 2001:160, 367; Bailey 2003:12; Tucker 2012:26-30).

Copper clothing buttons were also recovered from the site (Figures 4 and 5). Based on the size and location of the buttons, it is highly probable that the individual had been wearing knee breeches, a clothing style that was superseded by pantaloon trousers during the first few decades of the nineteenth century (Brooke 2003:130; Moore, Jr. and Haynes 2003:93-94). The buttons were plain, which is noteworthy because the Spanish government issued a royal decree in 1795 requiring the marking of military buttons with identifying emblems (Fenenga et al 2012). Plain copper buttons were most common prior to 1800; after this time, metal buttons possessing identifying marks such as stamps or maker's marks became more fashionable (Marcel 1994). The knee breeches and buttons suggest 41BX34 predates the Texas Revolution (1835-1836). The only earlier skirmishes between groups of 
European descent known to have occurred in the San Antonio area were those events associated with the Gutiérrez-Magee expedition of 1812-1813.

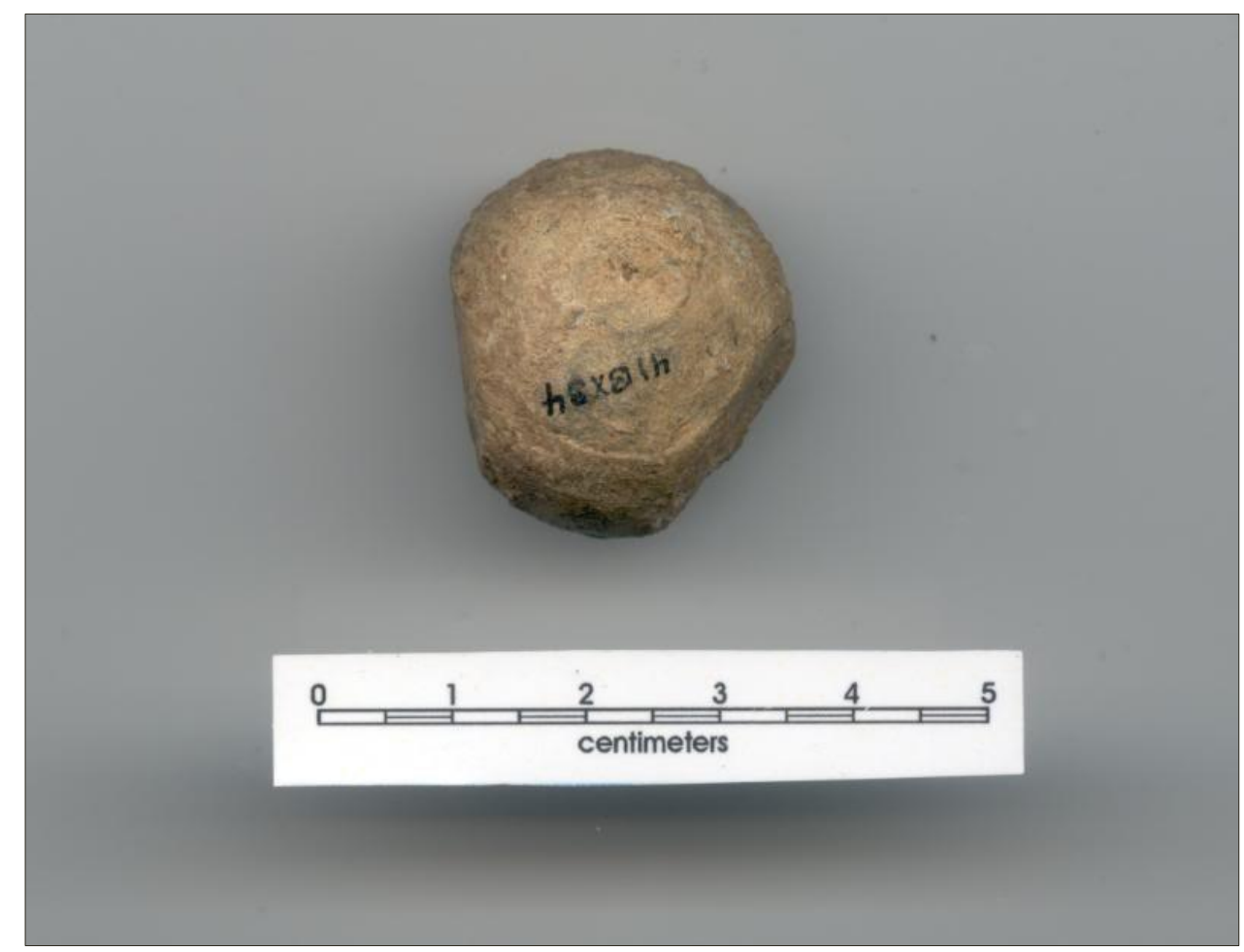

Figure 3. Four-ounce lead ball recovered at 41BX34. Photo courtesy of UTSA Center for Archaeological Research.

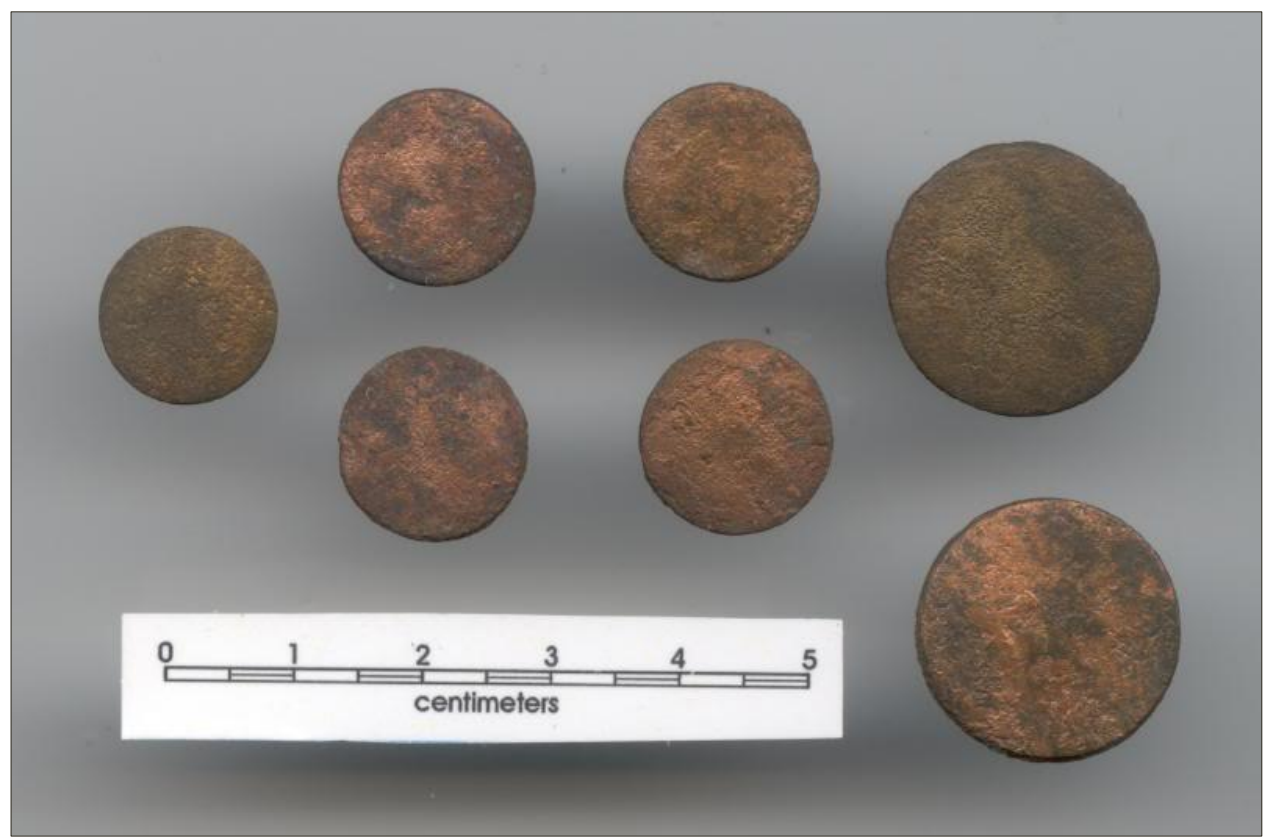

Figure 4. Clothing buttons recovered at 41BX34. Photo courtesy of UTSA Center for Archaeological Research. 


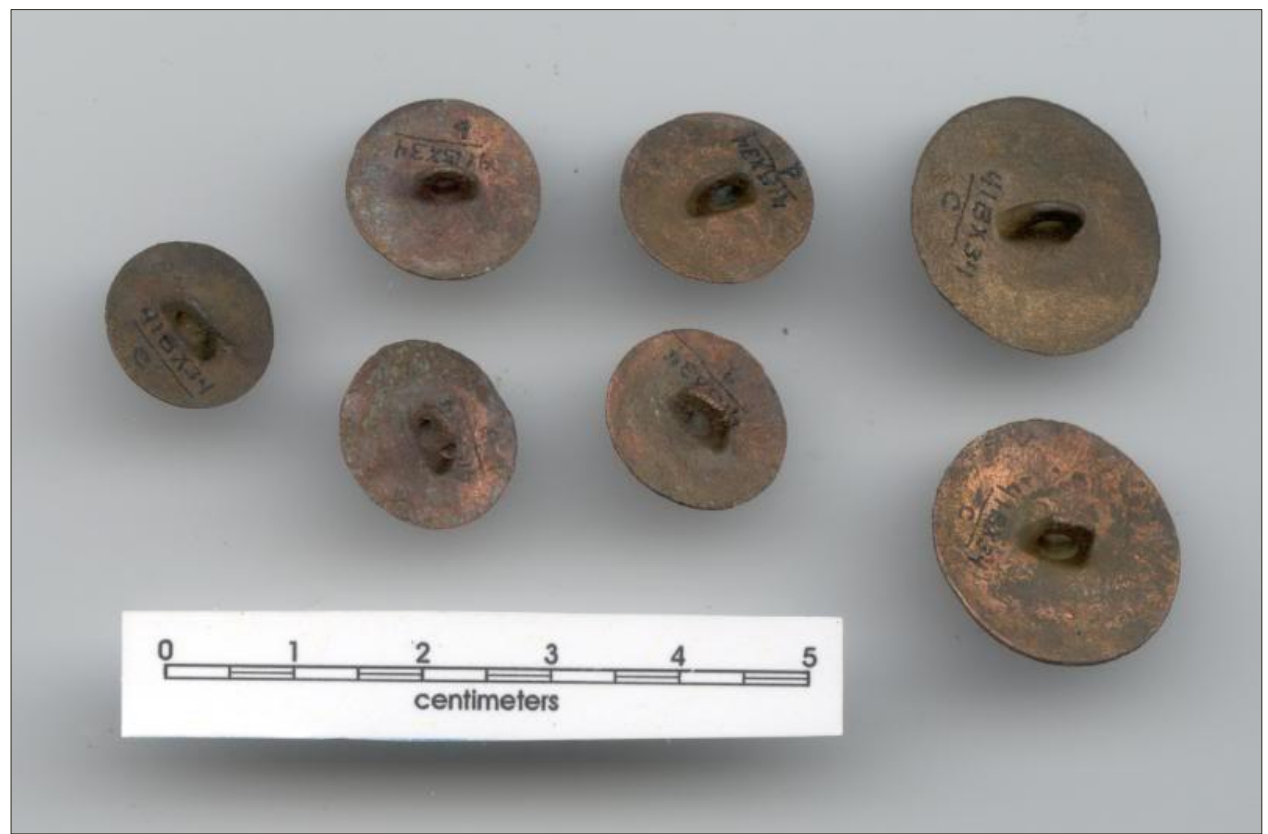

Figure 5. Reverse side of clothing buttons recovered at 41BX34. Photo courtesy of UTSA Center for Archaeological Research.

\section{THE GUTIÉRREZ-MAGEE EXPEDITION}

The Gutiérrez-Magee expedition of 1812-1813 was a filibustering expedition launched in an attempt to free Texas from Spanish colonial rule. The filibuster was led by José Bernardo Gutiérrez de Lara, a diplomat and revolutionary from the present-day Mexican state of Tamaulipas. While on a mission to seek American support for his cause, he received the backing of a former US Army officer, Augustus Magee. The two organized a force of 130 men in Natchitoches, Louisiana calling themselves the "Republican Army of the North." In August of 1812, the group crossed the Sabine River into Spanish Texas.

After capturing Nacogdoches, the expedition proceeded on to La Bahía (Goliad), gaining additional support along the way. In February of 1813, while the Spanish Royalists were laying siege to La Bahía, Augustus Magee fell ill and died under mysterious circumstances. He was replaced by another American, Samuel Kemper, who on March 29, 1813 led the Republican Army to its greatest success: the defeat of the Spanish Royalist army in the Battle of Rosalis. On April 1, 1813, Spanish Governor Manuel María de Salcedo surrendered San Antonio unconditionally. A few days after falling to the filibusters, Salcedo and 13 Royalist officers were marched out of town and executed.

The executions particularly appalled the American contingent of the Republican Army. In response, Kemper and over 100 American soldiers abandoned the cause and returned to the US. Over time, others began to lack confidence in Gutiérrez and his provisional government as well. Nevertheless, the Republicans were able to repel a Spanish invasion with a decisive victory on June 20, 1813 in the Battle of Alazán Creek (west of San Antonio). However, discontent with the new 
government continued. Gutiérrez was eventually replaced in early August 1813 by José Álvarez de Toledo y Dubois, a politician and revolutionary from Cuba. In the midst of Republican dissension and instability, the Spanish were able to regroup and regain control of the territory by routing the rebels on August 18, 1813 in the Battle of Medina (Thonhoff 2010a).

\section{GEOGRAPHIC CONTEXT}

To better understand 41BX34, it is important to assess the site in a geographic context. This includes examining the site in relation to historical activity in the region. The following is a deeper look into military engagements and historical routes in the area, for additional insight into what circumstances may have led to a mortally wounded individual being buried at this location.

\section{LOCAL MLITARY ENGAGEMENTS SOUTH OF SAN ANTONIO, 1812-1813}

At the time of the discovery, the Bexar County archivist speculated that the Blue Wing Road burial was associated with the Battle of Medina, one of two major battles that occurred in the general vicinity (Fox and Weeks 1968). According to numerous sources, this battle took place south of the Medina River in either southern Bexar or northern Atascosa County, near or along the Laredo Road (Hatcher 1908:222-226; Schwarz and Thonhoff 1985; Fehrenbach 2000:125-126; Thonhoff 2010b; Davis 2013; McDonald 2013:1809-1810; Folsom 2014:103-108). The engagement was primarily a running battle, and consisted of five or more events widely separated across the landscape. These included an initial encounter, the first engagement, a fighting retreat, the main battle, and a disorderly retreat. Given the varying accounts, it is reasonable to assume that the main engagement, a cannon battle, took place five or more miles south of the Medina River. This is at least seven to eight miles south of 41BX34 (Figure 6).

A second major battle, the Battle of Rosalis (also known as the Battle of Rosales, Battle of Salado, and the Battle of Rosillo), is said to have taken place on March 29, 1813 near the confluence of the San Antonio River and Salado Creek. Historical accounts identify five important landscape features associated with the battle (Cox 1990:3-5). These include the nearby La Bahía Road that the Republican army travelled on its way from La Bahía to San Antonio; the Salado Creek crossing(s); a western fork along the route that the Republican Army followed after crossing the creek; a ridge and hill complex between the river and creek; and the route continuation along the unnamed road northward (on the east bank and parallel to the San Antonio River). Based on the description, this engagement may have occurred less than 3 mi northeast of 41BX34. 


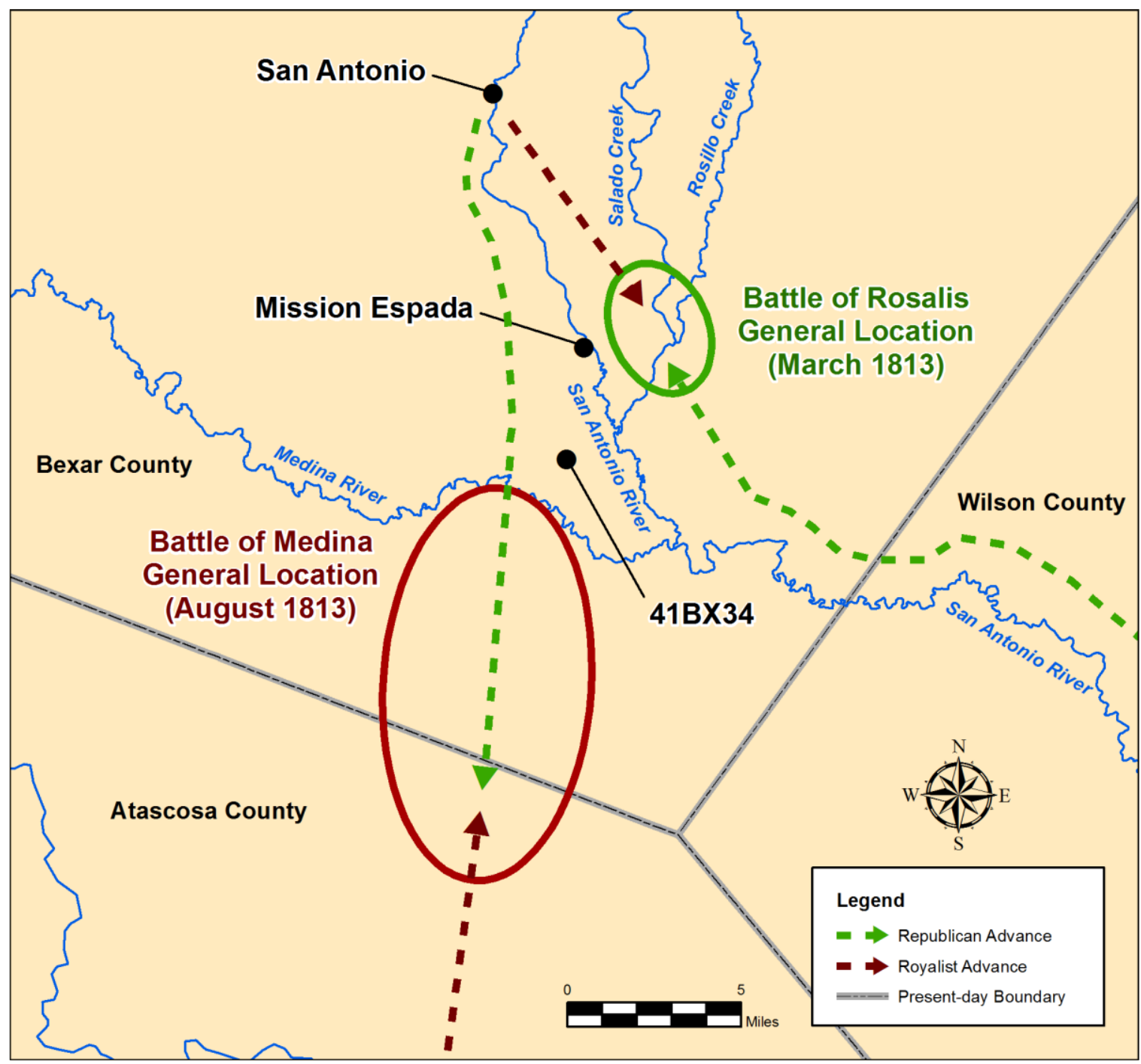

Figure 6. Approximate locations of battle sites in relation to 41BX34.

\section{HISTORICAL ROUTES}

During the Spanish colonial period, there were two major, post-1750 historical routes south of San Antonio to Medina River crossings. The first was commonly referred to as Camino Abajo, or the Lower Presidio Road (to Rio Grande). By 1800, the Lower Presidio Road appears to have fallen out of use (McGraw et al 1998:15; NPS 1998:8-11) and may have merged with the Laredo Road. The Laredo Road, the second route, linked San Antonio with Laredo. The Lower Presidio and Laredo Roads were part of a complex transportation network (Figure 7), whose alignments shifted over time in response to the changing needs of travelers (NPS 2011:20). Between the Medina River crossings and San Antonio, several Laredo Road routes have been identified on historical maps as having passed through the area at one time or another. A few even passed in the vicinity of the Blue Wing Road burial location. 
The Corpus Christi Road, depicted on the 1887 and 1897 maps of Bexar County produced by John D. Rullman, is a particular route of note. When geographically referenced to contemporary maps, the route passes near the west end of Blue Wing Road. Due to the age and countywide scale of the map, the accuracy of the exact route location is questionable. However, with some minor lateral shifting, this segment of the Corpus Christi Road (which generally paralleled known Laredo Road routes between the Medina River and San Antonio) likely evolved from a Laredo Road route (Figure 8) into the modern alignment of South Flores Road. Incidentally, site 41BX34 was recorded several hundred feet east of South Flores Road.

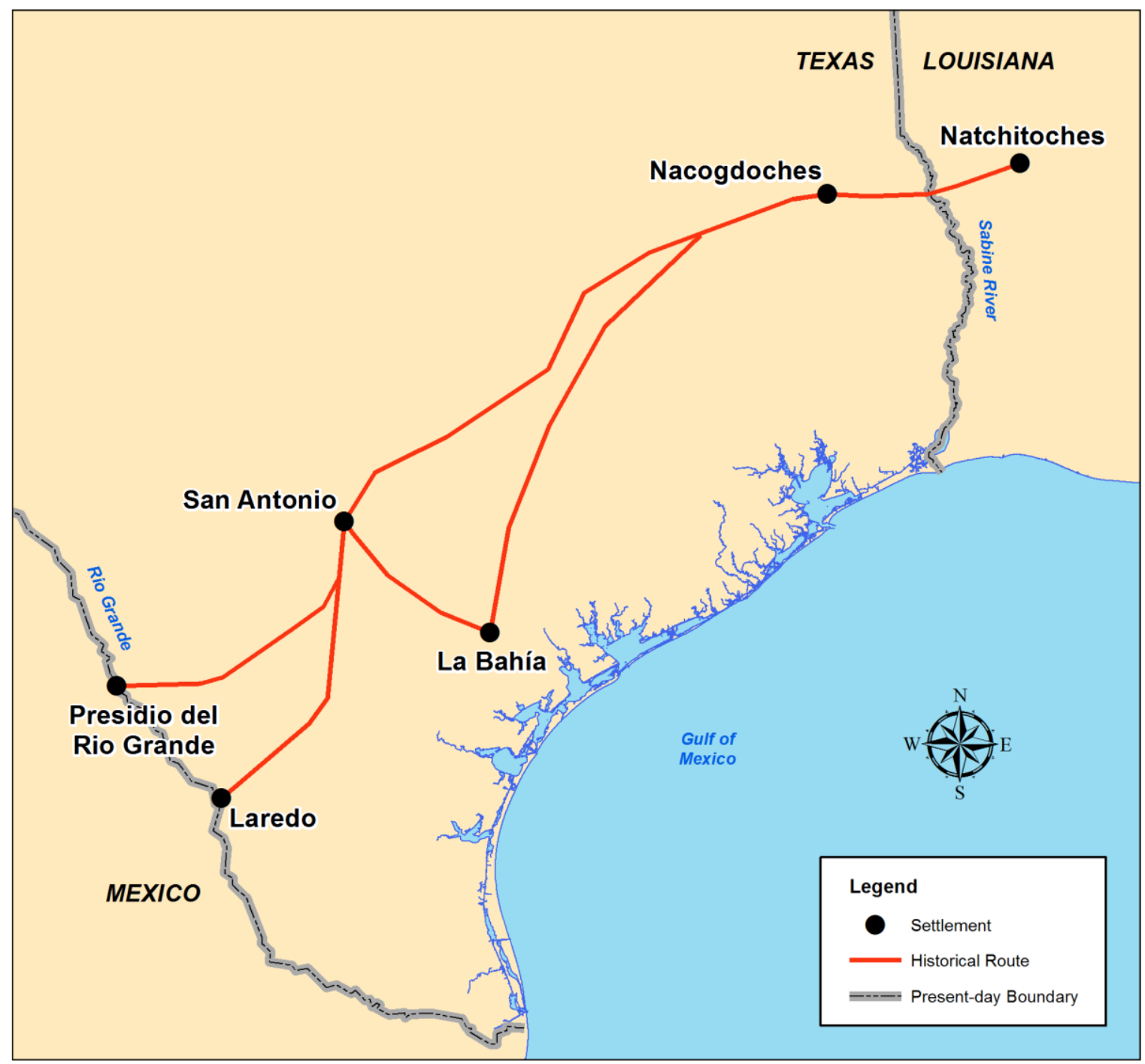

Figure 7. Regional map of historical routes . 


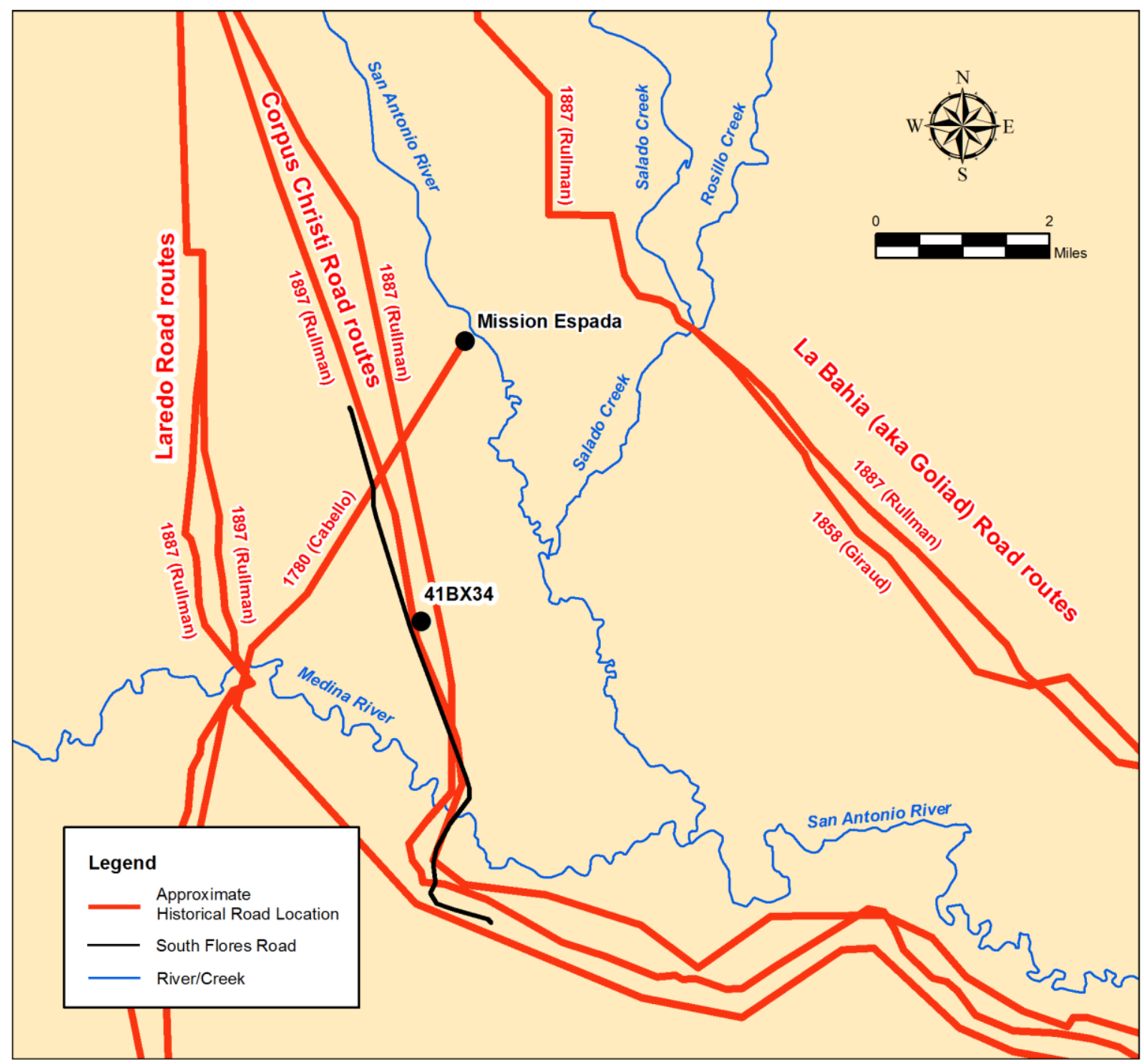

Figure 8. Historical routes in relation to 41BX34

\section{CONCLUDING THEORIES AND DISCUSSION}

As previously mentioned, a 4-ounce lead ball was recovered from the burial and, because of the size of the ball, it could not have been fired from a musket (Haecker and Mauck 1997:135; Tucker 2011:526-527). It would have to come from a grape or canister shot, which is typically fired from a cannon at close range to be most effective (Farwell 2001:160, 367; Bailey 2003:12; Tucker 2012:2630). This type of less-mobile artillery was usually positioned and fired from strategic, pre-established locations (Farwell 2001:52-54; Bailey 2003:9, 12, 15-19), a great possibility arises that an incident or skirmish occurred in the vicinity, and along a well-travelled route. Historical maps place one of the possible Laredo Road routes within several hundred feet of the site, further suggesting an incident occurred in the area of the burial. 
Scouting parties and other military detachments were not uncommon during the Gutiérrez-Magee expedition. Many of the early engagements between Royalist and Republican forces were initiated by scouts and detachments (Bradley 2015:45-47). Following the siege of La Bahía, a Republican scouting party sent ahead to San Antonio was successful in capturing 250 horses and taking 13 prisoners (Bradley 2015:53). Prior to the Battle of Alazán, Royalist forces captured 40 horses and 9 prisoners at a rebel outpost on Leon Creek. An additional 300 horses and 20 prisoners were captured later that same day at another outpost, an event that left 3 Republicans dead (Marshall 2015:48). Therefore, it is not unreasonable to assume that encounters involving exchanges of fire occurred outside of the known, major recorded battles.

The recovered button types and their locations in situ are also of special significance. This points toward the burial involving a Republican. Civilian volunteers (who were more likely to have worn knee breeches and plain buttons) comprised a sizeable portion of the Republican Army, especially in the early days when the rebellion was gaining traction (Edmondson 2000:38; McDonald 2013:18041805; Torget 2015:31).

There is still a question of the circumstances surrounding the death and burial. The Battle of Medina is believed to have been fought on or along the Laredo Road, but several miles south of 41BX34. Less than 100 men out of the Republican force of about 1,500 were able to escape alive (McDonald 2013:1809). The bodies of the fallen were left for 9 years before being collected and given a proper burial under an oak tree on the battlefield (Thonhoff 2010b). Numerous accounts of the battle noted the difficulty in travelling across the terrain (Schwarz and Thonhoff 1985; Thonhoff 2010b; Folsom 2014:104; Bradley 2015:86) and, for this reason, it is not likely that an individual struck in the neck with a canister shot could travel (even if carried) northward to 41BX34 without being overtaken by the pursuit of Spanish cavalry. Moreover, it is not plausible for there to have been Royalist artillery positioned that far north ahead of the initial encounter location for the wound to have been inflicted in the immediate vicinity.

This leaves the Battle of Rosalis as the only other known major clash in the region south of San Antonio between the Spanish Royalist forces and the rebel Republican Army of the North. The Republicans lost 6 men in the battle and claimed victory. However, because of the geographic positioning of the battle site (on a ridge a few miles away from 41BX34 and across the San Antonio River), it seems unlikely that the Blue Wing Road burial is directly associated with this battle. Nevertheless, the possibility exists that a Republican detachment could have been sent across the river to scout an alternate route north to Mission Espada (Figure 9). According to accounts, the Republicans had planned to camp at Mission Espada when flankers discovered the Royalist Army setting an ambush (Cox 1990:3-5; Thonhoff 2010c.). These facts lead to the development of a new hypothesis regarding the Blue Wing Road burial. A Republican detachment likely encountered Royalists stationed along the route to Mission Espada, with an ensuing skirmish resulting in the death of the soldier whose remains were exhumed at 41BX34. The act of digging a grave is time consuming and would keep a soldier off his guard. Ample time and a relative sense of security are important variables that allow for the burial of a fallen soldier. This needed time and security were available in the wake of the Battle of Rosalis when the Republicans established control of the region. 


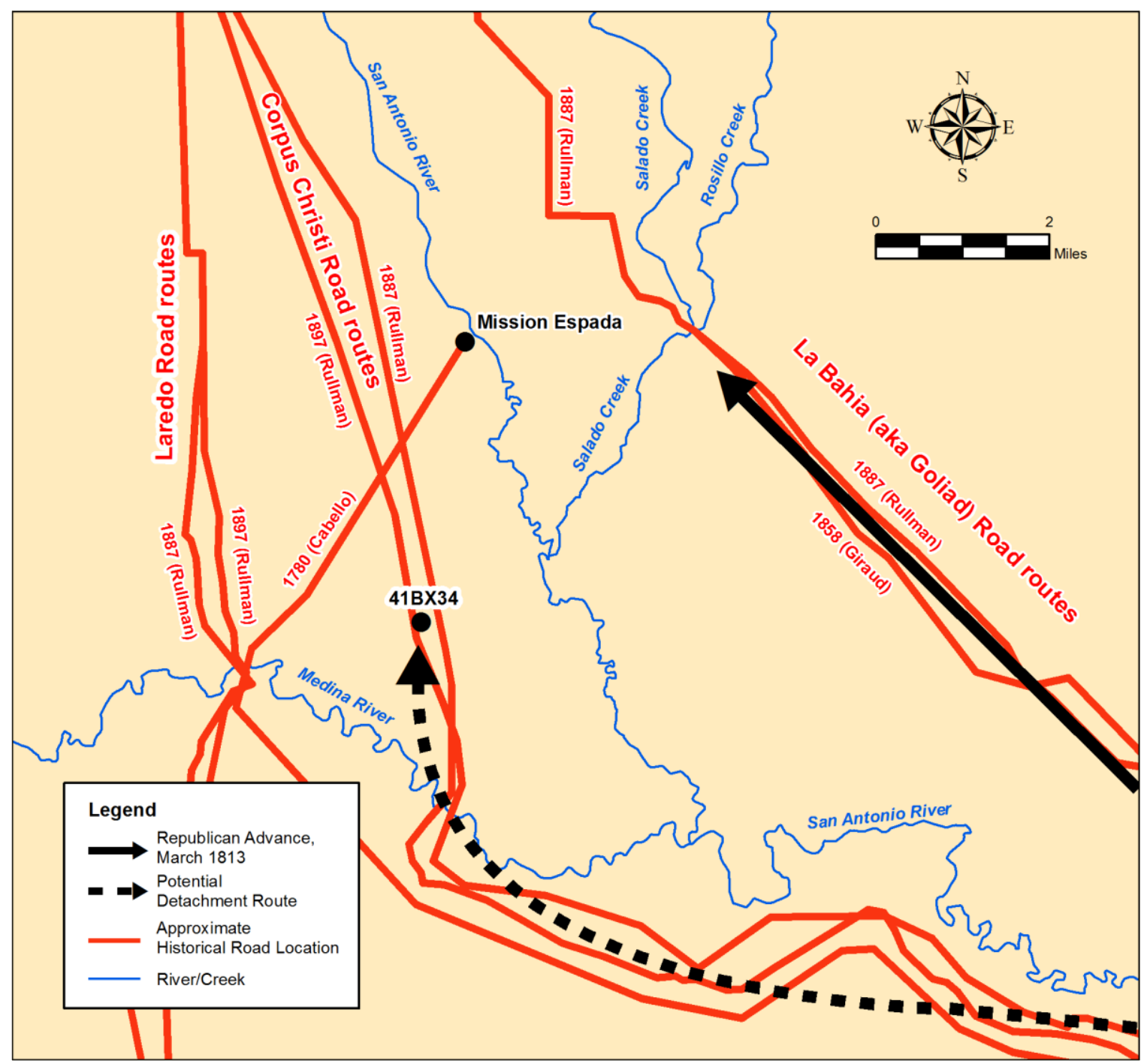

Figure 9. Historical routes in relation to 41BX34 and a plausible detachment route to Mission Espada.

\section{REFERENCES CITED}

Bailey, J.B.A., ed

2003 Field Artillery and Firepower. The Military Press, Oxford, England.

Bradley, E.

2015 We Never Retreat: Filibustering Expeditions into Spanish Texas 1812-1822. Texas A\&M University Press, College Station, Texas.

Brooke, I.

2003 Illustrated Handbook of Western European Costume, Thirteenth to Mid-nineteenth Century. Dover Publications, Mineola, New York. 
Butler, B.

1974 Letter to Anne A. Fox reporting the results skeletal analysis of Blue Wing Road burial, January 18. On file at the Center for Archeological Research, The University of Texas at San Antonio.

Cox, I.W.

1990 Field Survey and Archival Research for the Rosillo Creek Battleground Area, Southeast San Antonio, Texas. Center for Archaeological Research, the University of San Antonio. Archaeological Survey Report, No. 177.

Davis, V.T.

2013 "Remember the Battle of Medina," San Antonio Express News, August 17, 2013.

Dixon, E.J.

1999 Bones, Boats, and Bison: Archeology and the First Colonization of Western North America. University of New Mexico Press, Albuquerque, New Mexico.

Eckhardt, C.F.

1997 Texas Tales Your Teacher Never Told You. Taylor Trade Publishing, Lanham, Maryland

Edmondson, J.R.

2000 The Alamo Story: From Early History to Current Conflicts. Republic of Texas Press, Plano, Texas.

Farwell, B.

2001 The Encyclopedia of Nineteenth Century Land Warfare: An Illustrated View. W.W. Norton and Company, New York, New York.

Fehrenbach, T.R.

2000 Lone Star: A History of Texas and the Texans. Da Capo Press, Cambridge, Massachusetts.

Fenenga, G., D.G. Foster, J.W. Foster, L.C. Pollack, and B.A. Crane

2012 A Military Button from Baja California. California Fire Archaeology Program Resource.

Folsom, B.

2014 Joaquin de Arredondo in Texas and Northeastern New Spain, 1811-1821. Unpublished doctoral dissertation. University of North Texas, Denton, Texas.

Fox, A. and H. Weeks

1968 Site Record Form for 41BX34, in the Texas Historical Commission's Archeological Sites Atlas.

Haecker, C.M. and J.G. Mauck

1997 On the Prairie of Palo Alto: Historical Archaeology of the U.S. Mexican War Battlefield. Texas A\&M University Press, College Station, Texas. 
Hatcher, M.A., trans.

1908 "Joaquin de Arredondo's Report of the Battle of Medina, August 18, 1813." Quarterly of the Texas State Historical Association, Volume 11 (January): 220-236.

Knüsel, C and M.J. Smith, eds.

2014 The Routledge Handbook of the Bioarchaeology of Human Conflict. Routledge, New York, New York.

Larsen, C.S.

2015 Bioarchaeology: Interpreting Behavior from the Human Skeleton. Cambridge University Press, Cambridge, England.

Marcel, S.E.

1994 Buttoning Down the Past: A Look at Buttons as Indicators of Chronology and Material Culture. University of Tennessee Honors Thesis Projects, Knoxville, Tennessee.

Marshall, R.P.

2015 The Battle of the Alazán: First Texas Republic Victorious. Southwestern Historical Quarterly 119(1): 44-57.

Matovina, T. and J. de la Teja, eds.

2013 Recollections of a Tejano Life: Antonio Menchaca in Texas History. University of Texas Press, Austin, Texas.

McDonald, D.R.

2013 José Antonio Navarro: In search of the American Dream in Nineteenth-Century Texas. Texas A\&M University Press, College Station, Texas.

McGraw, A.J., J.W. Clark, Jr., and E.A. Robbins, eds.

1998 A Texas Legacy: The Old San Antonio Road and the Caminos Reales, a Tricentennial History, 16911991. Second printing. Texas State Department of Highways and Public Transportation, Austin, Texas.

McKern, T.W. and T.D. Stewart

1957 Skeletal Age Changes in Young American Males. Quartermaster Research and Development Command Technical Report, EP-45, Natick, Massachusetts.

Moore, R.J., Jr. and M. Haynes

2003 Lewis \& Clark - Tailor Made, Trail Worn: Army Life, Clothing, and Weapons of the Corp of Discovery. Faircountry Press, Helena, Montana.

Munoz, C.

2014 "A Probable Casualty of the First Texas Revolution, the Gutierrez-Magee Expedition of 1928-1813." Presented at the Southern Texas Archeological Association Quarterly Meeting, San Antonio, Texas, July 26. 
National Park Service (NPS)

1998 National Historic Trail Feasibility Study and Environmental Assessment: El Camino Real de los Tejas, Texas and Louisiana. Document on file at National Trails-Intermountain Office. Santa Fe, New Mexico.

2011 El Camino Real de los Tejas National Historic Trail Final Comprehensive Management Plan/Environmental Assessment, Louisiana and Texas. Document on file at National TrailsIntermountain Office. Santa Fe, New Mexico.

Schwarz, T., and R.H. Thonhoff

1985 Forgotten Battlefield of the First Texas Revolution: The Battle of Medina, August 18, 1813. Eakin Press, Austin, Texas.

Thonhoff, R.H.

2010a Gutierrez-Magee Expedition. Handbook of Texas Online (http://www.tshaonline.org/handbook/online/articles/qyg01), accessed February 05, 2016. Published by the Texas State Historical Association.

2010b Battle of Medina. Handbook of Texas Online. (http://www.tshaonline.org/handbook/online/articles/qfmo1), accessed February 05, 2016. Published by the Texas State Historical Association.

2010c Battle of Rosillo. Handbook of Texas Online (http://www.tshaonline.org/handbook/online/articles/qfr02), accessed February 05, 2016. Published by the Texas State Historical Association.

Torget, A.J.

2015 Seeds of Empire: Cotton, Slavery, and the Transformation of the Texas Borderlands, 1800-1850. UNC Press Books, Chapel Hill, North Carolina.

Tucker, S.C., ed

2011 The Encyclopedia of North American Indian Wars, 1607-1890: A Political, Social and Military History. ABC-CLIO, Santa Barbara, California.

2012 The Encyclopedia of the War of 1812: A Political, Social and Military History. ABC-CLIO, Santa Barbara, California.

Trotter, M. and G.C. Gleser

1958 A Re-evaluation of Estimation of Stature based on Measurements of Stature taken during Life and of Long Bones after Death. American Journal of Physical Anthropology 16(1): 79-123. 